\title{
Partitioning Defective 3 Homolog
}

National Cancer Institute

\section{Source}

National Cancer Institute. Partitioning Defective 3 Homolog. NCI Thesaurus. Code C125529.

Partitioning defective 3 homolog (1356 aa, $\sim 151 \mathrm{kDa}$ ) is encoded by the human PARD3 gene. This protein is involved in signal transduction, tight junction formation and asymmetric cell division. 